of the most disturbing times for many parents was after discharge, when they were again faced with repeated coughing and vomiting after the relief afforded by the child's admission to hospital.

Parents had little prior knowledge of whooping cough, and $81 \%$ found it more serious than they had imagined. Television programmes about the disease had given little idea of its potential severity. Almost all mothers had been worried that their child might die, though later the major fear was the possibility of permanent chest trouble. These worries need to be explored with parents during the child's admission, and one function of follow up should be to reassure parents about the likely outcome. Parental opinion about vaccination underlines both the power and the weakness of the media. ${ }^{20}$ Almost all knew about the "brain damage scare," yet only one was able to give a reasonably accurate estimate of the incidence of brain damage.

Finally, the experiences of parents in contact with health services ranged from very satisfactory to execrable. Problems arose both in general practice and in hospitals from doctors' ignorance about the illness; their comments, such as "too young to have whooping cough"; their unwillingness to accept the mother's account of the child's illness or consider the diagnosis; and sometimes their apparent ignorance of the availability of medical skill. Whooping cough may certainly be difficult to diagnose. The child often appears deceptively well between spasms, but in this study mothers' clearcut histories were often disregarded. Two thirds of mothers had been sure that their child had whooping cough, often despite medical denials, and there was often great relief when the diagnosis was finally confirmed, a reaction noted previously in the context of other childhood illnesses. ${ }^{21} 22$

We thank the Department of Health and Social Security for supporting the work.

\section{References}

1 Royal College of General Practitioners. Report from the Swansea research unit. Br Med 1981;282:23-6.

2 Pollock TM, Miller E, Lobb J. Severity of whooping cough in England before and after the decline in pertussis immunisation. Arch Dis Child 1984;59:162-5.

3 Walker E Pinkerton IW, Love WC Chaudhuri AKR, Datta JB Whooping cough in Glasgow 1969-80. F Infect 1981;3:150-8.

4 Robinson DA, Mandal BK, Ironside AG, Dunbar EM. Whooping cough-a study of severity in hospital cases. Arch Dis Child 1981;56:687-91.

5 Johnston IDA, Anderson HR, Lambert HP, Patel S. Respiratory morbidity and lung function after whooping cough. Lancet 1983 ;ii:1104-8.

6 Graham P, Rutter $M$. The reliability and validity of the psychiatric assessment of the child. II Interview with the parent. Brf Psychiatry 1968;114:581-92.

7 Jenkins S, Bax M, Hart H. Behaviour problems in pre-school children. 7 Child Psychol Psychiatr $1980 ; 21: 5-17$

8 Gayton WF, Friedman SB, Tavormina JF, Tucker F. Children with cystic fibrosis. Psychological test findings of patients siblings and parents. Pediatrics 1977;59:888-94.

9 Binger CM, Ablin AR, Feuerstein RC, Kushner JH, Zoger S, Mikkelsen C. Childhood leukemia Emotional impact on patient and family. N Engl f Med 1969;280:414-8.

10 Vance JC, Fazan LE, Satterwhite B, Pless IB. Effects of nephrotic syndrome on the family: a controlled study. Pediatrics 1980;65:948-55.

11 Christie AB. Infectious diseases: epidemiology and practice. Edinburgh: Churchill Livingstone, 1980.

12 Grob PR, Crowder MJ, Robbins JF. Effects of vaccination on severity and dissemination of whooping cough. Br Med f 1981;282:1925-8.

13 Wynne J, Hull D. Why are children admitted to hospital? BrMed f 1977;ii:1140-2.

14 Prugh DG, Staub EM, Sands HH, Kirschbaum RM, Lenihan EA. A study of the emotional reactions of children and families to hospitalisation and illness. Am f Orthopsychiatr 1953:23:70-106.

15 Vernon DTA, Schulman JL, Foley JM. Changes in children's behaviour after hospitalisation. Am f Dis Child 1966;111:581-93.

16 Brain DJ, Maclay I. Controlled study of mothers and children in hospital. BrMed f 1968;i:278-80.

17 Douglas JWB. Early hospital admissions and later disturbances of behaviour and learning. Dev Med Child Neurol 1975:17:456-80

18 Quinton D, Rutter M. Early hospital admissions and later disturbances of behaviour. Dev Med Child Neurol 1976;18:447-59.

19 Department of Health and Social Security. Whooping cough: reports from the Committee on Safety of Medicines and the foint Committee on Vaccination and Immunisation. London: HMSO, 1981

20 Church MA. Return of whooping cough. Br Med f 1979;i: 195

21 Lansdown R. More than sympathy. The evervday needs of sick and handicapped children and their families. London: Tavistock Publications, 1980.

22 Burton L. The family life of sick children. London: Routledge and Kegan Paul, 1975.

(Accepted 21 January 1985)

\title{
Should all casualty radiographs be reviewed?
}

\author{
J WARDROPE, P M CHENNELLS
}

\begin{abstract}
The effect on the management of patients of routine reporting of casualty radiographs by radiologists was reviewed. The overall prevalence of error by casualty doctors was $6 \cdot 2 \%$. Many of these errors, however, were trivial and did not alter treatment. In only $1.1 \%$ of the cases reviewed did the report of $x$ ray films appreciably alter the management of the patient. A severity score was introduced to highlight those anatomical areas in which important lesions were overlooked most often. Radiologists'
\end{abstract}

\footnotetext{
Departments of Accident and Emergency and Diagnostic Radiology, General Infirmary, Leeds LS1 3EX

J WARDROPE, MB, FRCS, research registrar

P M CHENNELLS, MB, FRCR, consultant radiologist
}

Correspondence to: Mr J Wardrope, Accident and Emergency Department, Royal Hallamshire Hospital, Sheffield S10 2JF. reports on radiographs of the chest, face, skull, and wrist had the greatest effect on management of patients, while reports on radiographs of fingers, hands, shoulders, long bones, and toes seldom altered treatment.

\section{Introduction}

Casualty officers interpret casualty radiographs reasonably accurately. ${ }^{12}$ Some errors have little influence on the management of patients as the treatment is based on clinical assessment. Other errors, however, may have serious consequences, and it has been recommended that all casualty radiographs be reported by a radiologist.' The increasing workload presented to the accident department imposes a large burden on the radiologist, who may have to report many radiographs to identify one important error.

We undertook a survey to identify which errors had the greatest effect on management of patients and to ascertain whether any anatomical areas could be excluded from routine reporting. 


\section{Methods}

The accident department at this hospital deals with over 65000 new patients a year. A radiologist of consultant or senior registrar status attended the accident department daily to report the radiographs of patients managed within the department during the preceding 24 hours. The radiologist had access to the clinical notes at the time of reporting. Patients admitted or referred to other departments were not included in this scheme. When the radiologist disagreed with the casualty officer's report the case was discussed with one of the senior members of the staff in the department and a decision made on the need for further action. For the past year all such cases of officer's report was false negative in 832 cases $(5 \cdot 0 \%)$ and false positive in 199 $(1 \cdot 2 \%)$. In only 190 cases $(1 \cdot 1 \%)$ did the radiologist's report alter the management of the patient (that is, an important error had been made).

The table lists the details of the important errors and the severity score given to each one. Some categories had more than one value for each error. This arose because the management of each case depended on factors other than the radiograph-for example, 10 patients with lobar collapse were missed by the casualty officers. Six of these were recalled and given treatment as outpatients (severity score of three); in three cases the general practitioner was asked to follow up the patient (score of two); and one patient was admitted for inpatient treatment (score of four).

Details of important errors (those that altered management) and severity scores

\begin{tabular}{|c|c|c|c|c|c|c|}
\hline Area of body & $\begin{array}{l}\text { No of } \\
\text { radiographs }\end{array}$ & $\begin{array}{l}\text { Total No of } \\
\text { errors }\end{array}$ & $\begin{array}{l}\text { Important } \\
\text { errors }\end{array}$ & $\begin{array}{l}\text { No of important } \\
\text { errors }\end{array}$ & $\begin{array}{l}\text { Severity score } \\
\text { per error }{ }^{\star}\end{array}$ & $\begin{array}{l}\text { Total severity } \\
\text { score } \\
\text { for area } \\
\text { of body }\end{array}$ \\
\hline Chest & 2056 & 148 & $\begin{array}{l}\text { Lobar collapse } \\
\text { Pneumothorax } \\
\text { Mass lesion } \\
\text { Fractured ribs } \\
\text { Other }\end{array}$ & $\begin{array}{r}10 \\
4 \\
8 \\
5 \\
5\end{array}$ & $\begin{array}{c}3(6), 2(3), 4(1) \\
3(3), 4(1) \\
3 \\
2 \\
2\end{array}$ & 85 \\
\hline Wrist & 1276 & 126 & $\begin{array}{l}\text { No bony injury (plaster } \\
\text { of Paris removed) } \\
\text { Undisplaced greenstick fracture } \\
\text { Fractured scaphoid } \\
\text { Colles' fracture } \\
\text { Avulsion fractures } \\
\text { Other }\end{array}$ & $\begin{array}{r}16 \\
10 \\
11 \\
2 \\
2 \\
3\end{array}$ & $\begin{array}{c}0 \cdot 5 \\
3(7), 1(3) \\
3 \\
3 \\
2 \\
2\end{array}$ & 81 \\
\hline Face & 1345 & 70 & $\begin{array}{l}\text { Zygoma fracture } \\
\text { Blow out of orbit } \\
\text { Conjunctival foreign body } \\
\text { Foreign body wound }\end{array}$ & $\begin{array}{l}8 \\
7 \\
2 \\
1\end{array}$ & $\begin{array}{c}3(6), 2(2) \\
3 \\
3 \\
3\end{array}$ & 52 \\
\hline Skull & 1359 & 35 & $\begin{array}{l}\text { Linear fractures } \\
\text { Depressed fracture } \\
\text { Pineal shift }\end{array}$ & $\begin{array}{l}8 \\
2 \\
1 \\
3\end{array}$ & $\begin{array}{c}4(4), 2(4) \\
5 \\
3 \\
2\end{array}$ & 43 \\
\hline Abdomen & 994 & 36 & $\begin{array}{l}\text { Small bowel obstruction } \\
\text { ? subacute obstruction } \\
\text { Renal stones } \\
\text { Gall stones } \\
\text { Other }\end{array}$ & $\begin{array}{l}3 \\
2 \\
5 \\
2 \\
2\end{array}$ & $\begin{array}{c}4(2), 1(1) \\
2 \\
2 \\
2 \\
2\end{array}$ & 31 \\
\hline Foot & 852 & 83 & $\begin{array}{l}\text { Navicular fracture } \\
\text { Calcaneal fracture } \\
\text { Stress fracture } \\
\text { Other }\end{array}$ & $\begin{array}{l}5 \\
3 \\
2 \\
2\end{array}$ & $\begin{array}{l}2 \\
3 \\
1 \\
1 \\
2\end{array}$ & 30 \\
\hline Knee & 667 & 36 & $\begin{array}{l}\text { Fibular head fracture } \\
\text { Tibial plateau fracture } \\
\text { Tibial spine fracture } \\
\text { Osteochondritis dissecans } \\
\text { Greenstick femur }\end{array}$ & $\begin{array}{l}2 \\
3 \\
2 \\
1 \\
3 \\
1\end{array}$ & $\begin{array}{l}3 \\
3 \\
3 \\
3 \\
3 \\
3\end{array}$ & 30 \\
\hline Spine & 592 & 56 & $\begin{array}{l}\text { Fracture (C7) } \\
\text { Wedge fracture } \\
\text { Spondylolisthesis } \\
\text { Malalignment (C5) }\end{array}$ & $\begin{array}{l}1 \\
4 \\
2 \\
1\end{array}$ & $\begin{array}{l}5 \\
5 \\
2 \\
2 \\
3\end{array}$ & 20 \\
\hline Elbow & 695 & 62 & $\begin{array}{l}\text { Fractured radial head } \\
\text { Supracondylar fracture } \\
\text { Other }\end{array}$ & $\begin{array}{l}7 \\
7 \\
1 \\
2\end{array}$ & $\begin{array}{c}1(4), 3(3) \\
3 \\
2\end{array}$ & 20 \\
\hline Ankle & 1595 & 85 & $\begin{array}{l}\text { Lateral malleolus fracture } \\
\text { Posterior malleolus fracture } \\
\text { No bony injury }\end{array}$ & $\begin{array}{l}4 \\
4 \\
3 \\
4\end{array}$ & $\begin{array}{c}2 \\
3 \\
0.5\end{array}$ & 19 \\
\hline Hip & 202 & 11 & $\begin{array}{l}\text { Fractured neck of femur } \\
\text { Effusion } \\
\text { Fractured greater trochanter }\end{array}$ & $\begin{array}{l}3 \\
2 \\
1\end{array}$ & $\begin{array}{l}4 \\
3 \\
1\end{array}$ & 19 \\
\hline Pelvis & 71 & 16 & $\begin{array}{l}\text { Fractured pubic ramus } \\
\text { Fractured sacrum }\end{array}$ & $\begin{array}{l}1 \\
3 \\
1\end{array}$ & $\begin{array}{l}1 \\
3 \\
1\end{array}$ & 10 \\
\hline Shoulder & 795 & 34 & $\begin{array}{l}\text { Fractured neck of humerus } \\
\text { Fractured glenoid }\end{array}$ & 1 & $\begin{array}{l}3 \\
3\end{array}$ & 6 \\
\hline Hand & 1002 & 65 & $\begin{array}{l}\text { Fractured metacarpal } \\
\text { Enchondroma }\end{array}$ & 1 & $\begin{array}{l}3 \\
2\end{array}$ & 5 \\
\hline Fingers & 1661 & 90 & $\begin{array}{l}\text { Fractured proximal phalanx } \\
\text { No body injury }\end{array}$ & $\frac{1}{2}$ & $\begin{array}{c}3 \\
0.5\end{array}$ & 4 \\
\hline $\begin{array}{l}\text { Toes } \\
\text { Long bones }\end{array}$ & $\begin{array}{l}588 \\
965\end{array}$ & $\begin{array}{l}58 \\
22\end{array}$ & $\begin{array}{l}\text { None } \\
\text { None }\end{array}$ & & & \\
\hline
\end{tabular}

^Figures in parentheses are numbers of errors with that severity score.

disagreement were recorded. The records were reviewed in those cases in which further action was necessary and the effect of the report of the $x$ ray film on the patient's management assessed.

A severity score was assigned to each case in which there was disagreement. This score was based on decisions on management made by the senior member of the accident unit staff at the time the error was brought to their attention. Thus if no action was taken a score of 0 was given; if the current treatment was unnecessary and stopped (false positive), 0.5 ; if symptomatic treatment might be needed, 1 ; if treatment by a general practitioner was needed, 2 ; if outpatient treatment or follow up was needed, 3 ; if inpatient treatment or follow up was needed, as in a case of failure to notice a fractured neck of femur, 4 ; and for errors that were potentially life threatening, 5.

\section{Results}

A total of $16713 \times$ ray films were reviewed. In 1031 cases $(6 \cdot 2 \%)$ the reports of the radiologist and the casualty officer disagreed; the casualty
The highest number of important errors was made in interpreting radiographs of the chest, wrist, face, skull, and abdomen. In the chest lobar collapse, especially of the right upper and left lower lobes, was the abnormality most often missed. Fracture in the region of the inferior orbital margin proved the most difficult problem in the face. As in other studies casualty officers missed a small but appreciable number of fractures of the skull. ${ }^{34}$

Most of the important errors were made by the senior house officers or doctors doing occasional sessional work. The consultants, registrars, and general practitioner clinical assistants seldom made important errors. The senior house officers, however, saw most of the new patients in our department.

No effort was made to audit the accuracy of the radiologist. A few cases in which important fractures were missed by both the radiologist and the casualty officer were discovered when the patient returned because of persistent symptoms. The radiologist's report on radiographs of toes, fingers, hands (excluding wrists), and shoulders had little effect on the care of patients in our department during the year of the survey. 


\section{Discussion}

Out of hours radiographic reporting by junior radiologists in their first, second, and third years of training was examined by Seltzer $e t$ $a l .{ }^{5}$ In their study $6.3 \%$ of the junior radiologists' reports were altered by their senior colleagues. Two thirds of the alterations were clinically important. De Lacey et al compared the reporting of radiographs by casualty officers with that by consultant radiologists: $83 \%$ of the reports by casualty officers were correct and $7 \%$ incorrect, and they were unsure of the diagnosis in $10 \%$. There was a $4 \%$ error in the reports by consultant radiologists.

Carew-McColl reported an overall error of $3.9 \%$ and a prevalence of false negative reports of $4.4 \%$ in the reporting of $x$ ray films by casualty officers. ${ }^{3}$ These figures compare with an overall error of $6 \cdot 2 \%$ in our study.

The number of serious injuries missed by the casualty officers was small but important. By using the severity score we highlighted those areas in which important radiological abnormality was misinterpreted-that is, areas where the score totalled 10 or more (table).

Radiographs of fingers, hands, toes, shoulders, and long bones in which the severity scores totalled less than 10 were obtained in about $30 \%$ of the total number of examinations ( 5000 patients). Only four patients in this category had their management altered as a result of the radiologist's report: two women, one with a fracture of the surgical neck of the humerus and one with a fracture of the glenoid, were recalled, given a broad arm sling, and kept under review in the fracture clinic. One patient with a fracture of the proximal phalanx was recalled and had the fracture fixed internally, and one patient with a fracture of the second metacarpal was recalled and had the hand immobilised in plaster of Paris.

The answer to our question "Should all casualty radiographs be reviewed?" is yes, but only if the review is carried out by experienced radiologists as the prevalence of errors made by junior radiologists is probably similar to that of errors made by casualty officers. ${ }^{5}$

The yield of important errors in some areas was very low-for example, 1000 radiographs of the hand were reviewed but only one case was found in which management was changed. In no case did the radiologist's report of radiographs of the toes alter a patient's treatment.

Radiologists may also miss important errors. In the study by
De Lacey et al $4 \%$ of the reports of consultant radiologists were in error and $1 \%$ equivocal; about half these errors were clinically important. We did not attempt to audit the radiologists' reports, but we know that a few important errors were made by the radiologists. It could be argued that the reporting on large numbers of radiographs from fairly unimportant areas might increase the likelihood of a more serious abnormality being overlooked.

The cost of reporting casualty radiographs in this department is small in relation to the total expenditure on casualty radiology. Six half sessions a week were performed by a consultant or senior registrar in radiology at a current cost of roughly $£ 4500$ a year.

We are not in a position to comment on the medicolegal aspects of the errors found. It is unlikely that litigation would follow if the patient was treated adequately despite an incorrect radiological diagnosis. The same might not apply, however, if the incorrect radiographic diagnosis resulted in inadequate or inappropriate treatment.

This study highlights certain lesions that are missed repeatedly by casualty officers, notably collapse of the left lower and right upper lobes, fractured mala and blow out fracture of the orbit, fractured scaphoid, and fractures of the navicula and calcaneum. Casualty officers should be taught how to interpret radiographs early in their attachment to an accident and emergency department. Each department should keep a library of the commonly missed lesions to highlight the difficulties in diagnosis in those areas.

We thank Mr D H Wilson and Mr M Flowers for permission to report on their patients and the registrars, senior registrars, and consultants in the departments of accident and emergency and diagnostic radiology for their help in recording the errors in interpretation of the radiographs.

\section{References}

1 de Lacey G, Barker A, Harper J, Wignall B. An assessment of the clinical effects of reporting accident and emergency radiographs. Br f Radiol 1980;53:304-9.

2 Mucci B. The selective reporting of $x$-ray films from the accident and emergency department. Injur 1983;14:343-5

3 Carew-McColl M. Radiological interpretation in the accident department. Br $\mathrm{f}$ Clin Pract 1983;37:375-8.

4 Guly HR. Missed diagnoses in an accident and emergency department. Injury 1984;15:403-6.

5 Seltzer SE, Hessel SJ, Herman PG, Swensson RG, Sheriff CR. Resident film interpretations and staff review. AJR 1981;137:129-33.

(Accepted 6 February 1985)

$\underset{\square}{\varpi}$

Diarrhoea is a symptom and not a disease and it should not be treated without a diagnosis. Functional diarrhoea is common ${ }^{12}$ but should be diagnosed only after careful consideration of organic causes. Some patients with chronic diarrhoea cannot be cured-for example, those who have had a large amount of intestine resected. Sometimes dietary advice is helpful. Nevertheless, when antidiarrhoeal drugs are necessary loperamide is often a good choice. It is more effective than diphenoxylate and less prone to cause side effects than codeine. Tolerance does not develop, nor does physical dependence occur. Thus there seems to be no contraindication to taking loperamide indefinitely. There must be one caveat. The drug has been in use for only 14 years.- $\mathrm{K}$ W HEATON, reader in medicine, Bristol.

1 Thompson WG, Heaton KW. Functional bowel disorders in apparently healthy people. Gastroenterology 1980;79:283-8.

2 Harvey RF, Salih SY, Read AE. Organic and functional disorders in 2000 gastroenterology outpatients. Lancet 1983; i:632-4.

\section{What are the cardiovascular hazards of pipe and cigar smoking?}

In many epidemiological studies the risks of mortality from various cardiovascular diseases in pipe and cigar smokers have been calculated to be slightly but not significantly greater than those in non-smokers. One study reports a risk for pipe smokers below that of non-smokers. ${ }^{1}$ The only major prospective British study has, at each subsequent update, shown risks for pipe and cigar smokers close to those for non-smokers (relative risk ranging from 0.99 to 1.03$),{ }^{2}$ The 1983 United States Surgeon General's Report concluded, "Smokers who have used only pipes or cigars do not appear to experience substantially greater coronary heart disease risks than nonsmokers." ${ }^{3}$ The Royal College of Physicians in its 1983 report, quoting from the results of a published study, concluded with regard to pipe and cigar smokers, "Their position on the continuum of risk is not entirely clear. Risk is definitely below that of men who smoke a pack or more of cigarettes a day." "In relation to specific sites, Auerbach and Garfinkel reported a higher incidence of atherosclerotic lesions of the aorta in pipe and cigar smokers than in non-smokers. ${ }^{5}$ According to Feinleib and Williams, the risk of peripheral vascular disease is not raised in pipe or cigar smokers, although it is so in cigarette smokers. ${ }^{6}$ Finally, it has been suggested that the tendency for pipe and cigar smokers not to inhale smoke into the lungs may protect them from cardiovascular risk. ${ }^{23}$ If so cigarette smokers who switch to pipes or cigars but continue to inhale may not avoid the risk.-FRANCIS J C ROE, independent consultant in toxicology and cancer research, London.

1 Best EWR. A Canadian study of smoking and health. Ottawa: Department of National Health and Welfare, 1966.

2 Doll R, Peto R. Mortality in relation to smoking. 20 years' observation on male British doctors. $B$ Med f 1976;ii:1525-36.

US Surgeon General. Cardiovascular disease. In: Health consequences of smoking. DHSS (PHS) 84-50204.

4 Royal College of Physicians. Health or smoking. London: Pitman Medical, 1983.

5 Auerbach $\mathrm{O}$, Garfinkel $\mathrm{L}$. Atherosclerosis and aneurysm of the aorta in relation to smoking habits and age. Chest 1980;78:805-9.

6 Feinleib H, Williams RR. Relative risks of myocardial infarction, cardiovascular diseases and peripheral vascular disease by type of smoking. In: Wynder EL, Hoffman D, Gori GB, eds. Modifying the risk for the smoker. Washington: DHEW, 1976:243-56. (DHEW publication No (NIH) 76-1221.) 